university, technical college or other institution approved by the Trustees. Two Perkin Centenary Scholarships are offered, each for two years, renew. able at the discretion of the Trustees for one further year, to enable candidates employed in an industrial firm or other institution concerned with the manufacture or the application of colouring matters to receive an education at a university or technical college. Each award will have a value of $£ 300$ per annum. There is no means test for the award, and a successful candidate is not debarred from receiving the whole or a part of his normal salary from his employers during his tenure of the Scholarship. Applications for either Fellowship or Scholarship must be submitted, on forms available from the Secretary to the Trustees, not later than May 1. Perkin Exchange Lectureships : a short-term appointment will be made from time to time by the Trustees to enable a senior teacher at any appropriate university, technical college or other institution to visit some similar establishment overseas in order to deliver a short course of lectures. In return, a visit to a British institution by some overseas scientist will be arranged. A longer-term appointment is also contemplated to permit the exchange of lecturers for a period of up to one year between comparable institutions in Britain and overseas.

The Trustees are Mr. H. Jackson (chairman), Dr. D. W. Hill, Dr. L. H. Lampitt, Mr. W. R. Mathers, Mr. M. W. Perrin and Sir Robert Robinson. The secretary to the Trustees is Dr. J. R. Ruck Keene, to whom inquiries relating to the above awards should be addressed, c/o The Chemical Society, Burlington House, London, W.1.

\section{Investigations on Coast Erosion in Britain}

IN an adjournment debate on March 5 in the House of Commons the subject of discussion was coast erosion. Mr. N. Nicolson agreed with the Waverley Committee that the intensity of research in this field should be increased, and asked a number of questions about the activities of the Hydraulics Research Board; he also urged the Ministry of Housing and Local Government to make grants for maintenance and repair and for temporary first-aid to works of coastal defence, as it is empowered to do and as the Waverley Committee has recommended. Replying for the Ministry, the Parliamentary Secretary, Mr. J. R. Bevins, declined to comment on Mr. Nicolson's argument that sea-defences should be made mainly a national charge, beyond pointing out that there is no obligation on the central government to provide the full cost of such schemes and that this would require legislation. Nevertheless, the Treasury has been paying up to 85 per cent of the capital cost of coast protection works carried out by local authorities since the end of the War, and on average more than half. On research into coast protection problems, Mr. Bevins said that an advisory committee on sea defence research was set up two years ago which has issued two reports. One of these dealt mainly with embankments on estuaries and the other with the movement of beach materials; the Advisory Committee is at present considering the effect of vegetation.

\section{European Organization for Nuclear Research}

Ат a Friday Evening Discourse, delivered at the Royal Institution on March 8, Sir Ben Lockspeiser, who is president of the Council of European Organization for Nuclear Research (C.E.R.N.), said that the resources, human and material, required for scientific research have grown in some fields to large dimensions in recent years. This is particularly so in the field of nuclear physics where the means necessary for conducting experiments have increased beyond the single capacities of most nations. The European Organization for Nuclear Research (see Nature, 178, 902; 1956) was, therefore, brought into being to enable twelve European countries to achieve together what they are unable to do alone. The first task of the Organization has been to provide itself with research tools, and two particle accelerators are being built at Meyrin, near Geneva: one, a 600-MeV. synchrocyclotron, in which the path of the accelerated particle is a flat spiral, and the other, a $25-\mathrm{GeV}$. proton-synchrotron, which accelerates the particle in a repeated circular path. Sir Ben outlined some of the scientific and technological problems presented in the course of their design and construction. The present staff, drawn from various countries, numbers about three hundred. A multi-national venture of this kind requires its own form of organization to govern itself and to maintain essential relation. ships with the governments of member States. It requires also an administration capable of dealing with both the present constructional period and the succeeding stage, now beginning, when scientists from various countries will be enabled to use the machines for limited periods dependent on their programme of work.

National Institute for Research in Nuclear Science

THE Chancellor of the Exchequer, in a written reply in the House of Commons on March 12, stated that the governing board of the National Institute for Research in Nuclear Science, under the chairmanship of Lord Bridges, has been constituted by the Lord President of the Council and himself, with the following representative members: Universities : Sir Philip Morris, Sir James Mountford, Prof. N. F. Mott, Prof. H. S. W. Massey, Prof. J. Diamond, Prof. R. E. Peierls and Dr. D. H. Wilkinson; University Grants Committee : Sir George Thomson, Mr. J. C. Gridley; Royal Society : Sir David Brunt; Atomic Energy Authority: Sir John Cockeroft, Sir Donald Perrott and Dr. B. F. J. Schonland; Department of Scientific and Industrial Research: Dr. H. W. Melville and Prof. P. M. S. Blackett.

\section{New Reactor at Harwell}

A NEW experimental low-energy reactor, NERO, is now operating at the Atomic Energy Research Establishment, Harwell. It became critical for the first time at $7.45 \mathrm{p} . \mathrm{m}$. on February 23, and its experimental programme is now beginning. The reactor will be used to investigate the design problems associated with the more advanced types of graphitemoderated power reactors now under study by the Authority. The reactor consists of a graphite stack which can be varied in size up to a cylinder of about $14 \mathrm{ft}$. diameter by $10 \mathrm{ft}$. high within a concrete biological shield $2 \mathrm{ft}$. thick. Fuel elements of differing types may be arranged within the graphite stack in any one of a number of possible lattice patterns. The restacking of the graphite to permit a change in the fuel element arrangement can be done in a few days. The reactor is controlled by two vertical cadmium control rods which can be moved into the graphite stack through the top of the biological shield. Cadmium 'shut off' or 'safety rods' are 